This article was downloaded by: [University College London]

On: 24 February 2015, At: 06:10

Publisher: Routledge

Informa Ltd Registered in England and Wales Registered Number: 1072954

Registered office: Mortimer House, 37-41 Mortimer Street, London W1T

3J H, UK

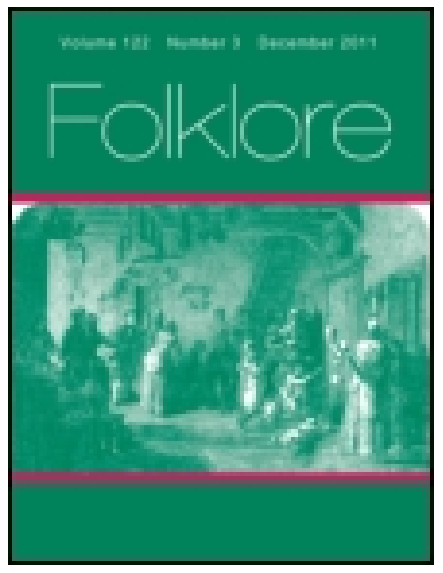

\title{
Folklore
}

Publication details, including instructions for authors and subscription information:

http:// www. tandfonline.com/loi/ rfol20

\section{Some Native Legends from Central Australia}

Mary E. B. Howitt

Published online: 06 Feb 2012.

To cite this article: Mary E. B. Howitt (1902) Some Native Legends from Central Australia, Folklore, 13:4, 403-417, DOI: 10.1080/0015587X.1902.9719323

To link to this article: http:// dx. doi.org/ 10.1080/0015587X.1902.9719323

\section{PLEASE SCROLL DOWN FOR ARTICLE}

Taylor \& Francis makes every effort to ensure the accuracy of all the information (the "Content") contained in the publications on our platform. However, Taylor \& Francis, our agents, and our licensors make no representations or warranties whatsoever as to the accuracy, completeness, or suitability for any purpose of the Content. Any opinions and views expressed in this publication are the opinions and views of the authors, and are not the views of or endorsed by Taylor \& Francis. The accuracy of the Content should not be relied upon and should be independently verified with primary sources of information. Taylor and Francis shall not be liable for any losses, actions, claims, proceedings, demands, costs, expenses, damages, and other liabilities whatsoever or howsoever caused arising directly or indirectly in connection with, in relation to or arising out of the use of the Content.

This article may be used for research, teaching, and private study purposes. Any substantial or systematic reproduction, redistribution, reselling, loan, sub-licensing, systematic supply, or distribution in any form to anyone is 
expressly forbidden. Terms $\&$ Conditions of access and use can be found at http://www.tandfonline.com/page/terms-and-conditions 


\title{
COLLECTANEA.
}

\section{Some Native 1 focends from Central Austrahia. ${ }^{i}$}

\author{
(Selected by Mary E. B. Howitt.)
}

The following legends are taken from a large collection made by the Rev. Otto Siebert, for a comprehensive work on the abori-

'[The specia] interest of these legends lies in the fact that "Mooramoora" was described hy a previous witness, Mr. Gason (The Dieyerje Tribe in Mr. Curr's 'Th" Australian Race, ii., 44-107), as a single being, not as a race of leings. "Mooramoora is a Cood Spirit or Divine Being; and although they have no form of religious worship, they speak of the Mooramoora with great teverence," In a language which possesses no article, and, apparently, no verbal plural (see Curr, The Azstration Race, $i, 10, I 1$ ), it is obvious that a noun of nultitude might easily be mistaken by is foreigner for a proper name. Mr. Crason's further statement, that the Dieri "have no form of relightons worship," is hardly consistent with his description of the rain-making ceremony, part of which he says is clesigned to be seen by the Mooramoora, "and immediately he cnuses clouds to appear in the heavens." If none appear, "they say the Mooramoora is cross with them." Mr. Howitt, moreover ( $J . A$ I., xx, 92), quotes Mr. Ciason for the following: "In the rare seasons which are too wet, the Dieri also have recourse to supplications to Mura Mura to restrain the sain, and Mr. Gason has seen the old men in a perfect state of frenzy, believing that their ceremonies had caused Murn-mura to send too much rain."

Otherwise the account of the Muramura hy Mr. Gason (who was a police(rooper stationed many years in the district) agrees in the main with Mr. Siebert's retiological myths. He gives Dieri legends crediting "the Moura* moora" (sing, no.) with the making of the sun, emus, mankind (who were first black lizards, made to walk erect with their tails cut off), the organisation into tribes and families, the marriage rules, the foundation of the various ceremonies, of the custom of knocking out teeth, \&c. Some of the ceremonies are pezformed within a circle traced with sand, within which the Mooramoon "is" supposed to be present, but which keeps out an evil being called Ktootshie, which Mr. Gason translates by dwil ("the devil is called Kootehie"), Mr. Gason's evidenee is cited and disenssed in the Golden Bough, i., 72 n., 86, 8\%, and in Magic and Religion, pp. 50, 56, 57, 62, 63,-ED.1 
gines of South-east Australia, which my father, Mr. A. W. Howitt, is now preparing for publication. Mr. Siebert is a missionary to the aborigines at Killalpanina, on the Cooper River, in Central Australia, and is a very zealous student of their laws and customs.

To any one familiar with the legends of other parts of Australia, with their half-animal, half-human actors, fabled ancestors of the modern race, these legends of the Dieri and kindred tribes will present some novel features, chiefly through the appearance of the Mura-muras.

These were beings of distinctly human form and actions, but always endowed with greater magical powers, and seemingly capable of more astounding feats, than the people of the present day. The perfecting of human beings out of shapeless creatures, the naming of the totems, and the institution of the sacred ceremonies are ascribed to them and duly recorded in certain of the legends.

The constant wandering of the Mura-muras is remarkable, They seem to have been possessed with the spirit of travel, and to have bestowed the present names on all natural objects, rocks, rivcrs, \&c., that they came across. They are now not infrequently pointed out by the blacks as solitary rocks or petrified tree trunks, whose shape they took when their work was done-perpetual witnesses to the aboriginal mind of the absolute truth of the legends. This wandering spirit is so constant in the Mura-mura legends that one is tempted to believe it to be a faint crystallised recallection of the first great spreading of the native race over the continent.

The interesting legend of the dark and light-coloured children is illustrated, as $\mathrm{Mr}$. Siebert says, by the present differences in colour between the tribes in that part of Australia. IJe tells us that in spite of the fusion of the tribes caused of late by the settlement of the country by the whites, the Wonkanguru and Wonkamala, northern neighbours of the Dieri, have a bluish-black tint of skin; while the Dieri themselves are reddish-brown, and the Tangara, who live on the western side of Lake Eyre, towards the West Australian boundary, are said by those of the Dieri who know them to be as light coloured as half-castes, and to be spoken of as Kana maralye or "light-coloured men."

In the legends of Warugatti, and of Woma and Kapiri, we are told of the origin of the emu, carpet-snake, and lizard, and their respective totems, while the legend of Pirinti is typical of the 
purely animal legends of South-eastern Australia. Nganto-warrina, the old Mura-mura who was turned into the moon, has his counterpart in many other moon legends; and it may be noted that we always find that the moon was once a man in the opinion of the Australian aborigine, while the Jack-and-the-Beanstalk incident of the tree growing up to the sky through magic is also frequently encountered.

The tract of country occupied by the Dieri tribe is on the delta of the Cooper, on the east of Lake Eyre. The Wonkanguru and Yaurorka are their immediate neighbours on the noth, and the Urabunna occupied a considerable tract on the west side of the lake.

\section{I. - Kuyimokuna. A Llegnd of THE DikR.}

A Mura-mura was once out by himself hunting in time of great drought, but could find no food. 'There was no game to be found, and as he sought for it in vain the Murn-mura Kuyimokuna, a clever boy, came to him and asked what he was looking for. "Kapiri and Woma," was the reply. "Follow me," said the boy, walking forward; and all at once he said "l)ig there." The man dug deep into the earth and found a zoma (carpet-snake), and in like manner the boy showed him other places where zomn were hidden. Thus be helped the elder Mura-mura on several days, till the others of his people envied him when they saw him return laden with game each night; so they asked him where he had got it. He told them to come with him, and his boy would show them where to find woma and kapiri (iguana). This they did, and the boy led them hither and thither to dig.

While they were doing this the boy became thirsty and drank out of their water-bag, forgetting to shut it up again, so that the water ran out. The people were all very angry at this and agreed to kill the boy, and did so when his friend and guardian was not there. Now this man felt in his liver that something was wrong with the boy. He could not sleep all night, and in the morning he set about following their tracks, till he came to where his friend lay dead. He wept bitterly for his boy. Then he separated the flesh from the bones, divided these from each 
other, and with them separately he killed all the people who had killed his friend.

This is how the Dieri got the custom of killing by "pointing the bone."

\section{Notes by the Rev. Otto Sienert.}

The liver is reyarded by these tribes as the seat of the affections. The Woma, or carpet-snake, is prized as an article of food. The reptiles hide in cracks in the sun-dried earth, from whence they are dug by the blacks. The Kapiri is the iguana, or lace-lizard.

A second "patron" of the boy Kuyimokuna was also associated in the "pointing of the bone" in some versions of the legend. Both avenged the death of the boy by "giving the bone" in common to the murderers of Kuyimokuna. For this reason it is almost always the case that two persons act together in "giving the bone;" one who points with it and also ties the end of the hair-cord which is fastened to it, tightly round his upper arm, in order that the blood may be driven through into the bone. 'The other person holds the end of another cord fastened to the bone, and goes through the same motions as he who is holding the bone. The bones of Kuyimokuna were divided into pieces and sent, as we would say, "to all points of the compass," carrying death wherever they came.

When all those who had taken part in the death of the boy Kuyimokuna had been done to death by his two champions, these two met the survivors of the people at a place called Nari-wolpu (nari is "death" in Dieri, and zelpu, "bone," in Wonkanguru). When the nurder was discussed at this meeting the principal champion of Kuyimokuna took two small staves of wood in his hand, tied them fast together with a cord, and buried them in the earth. "Sce," said he, turning to one of the survivors after the other and addressing each in turn. "Thou mournest for thy neji (elder brother), thou for thy ngaperi (father), \&c., and I for my tidnara (sister's son). We are all alike mourning for relations, let us now once more live in peace with each other and bury the whole affair." Out of this arose the custom called Pinti madi ya nguru, fast and unbreakable agreement-from pinti, agreement; madi, heavy, weighty; $y a$, and; ngurm, strong.

\section{1.-Nganto-warrina who blcame the Moon.}

Two young Murn-muras wers annoyed with their father, the old Mura mura Nganto-warrina, because he had gathered some nardoo 
and given none to them. One day their father saw them busy making long hooks (ngami) to pull out grubs (kuyikinka) from their holes in the gum trees. They told him they knew of a tree full of kuyikinkas, and the old Mura-mura climbed up to get some. As he climbed his sons kept urging him to go on higher, and all the time the tree raised itself or grew up further from the ground by reason of their magic. Then they set it on fire, and, as the burning tree rose up carrying Nganto-warrina, the sons saw that their father was being roasted, and one of them threw up a skin by his boomerang so that the old man might shelter himself from the heat.

Nganto-warrina still hangs in the sky as the moon, and the Dieri say the dark mark on its face is the place where the old Mura-mura covered himself with the skin.

\section{Notes By M. E. B. Howir?.}

$N_{g}$ ami are like long slender crochet-hooks made of wood, with which the blacks skilfully extract the grubs from their tunnel-like holes in the gum tree trunks.

Nardoo forms a staple article of food with these tribes, and has been well known to the whites since the unfortunate explorers Burke and Wills tried unsuccessfully to live on it, when Wills wrate in his diary that it was "not unpleasant starvation." Some of the seed actually collected by them, and afterwards found by Mr. A. W. Howitt's rescue party, is before me now. The so-called seeds are spore-cases of a species of Marsilia, a genus common to many parts of Australia. The "seeds" are oblong and flattened in shape, about an eighth of an inch in width and a quarter long, and chocolate-brown in colour.

\section{III.-Warukatti the EmU. A Tale of the Dieri.}

Two Mura-muras, who were husband and wife, once remarked that both had feathers on their bodies and that more were growing. They began to dance, and, as they did so, they went by accident into the fire, so that their legs were shrivelled up. The other Mura-muras noticed this, and said: "Go out from among us ; you do not belong to us; you are Warukatti." And they drove them away to run about as emus. 


\section{IV.-Origin of the Woma and Kapiri. A WonkangurU LEGEND.}

Naiyenimirara, Kurkali, Bulu-bulu, Watylina, and other Muramuras wanted to make some Womas. They consulted about the colours a Woma should be, but were not agreed about it, so Watylina went away, and the others drew long wavy lines on the ground and stuck sticks at the ends marked with the woma colours thus :

But they had scarcely done it when a fierce wind obliterated the marks and blew away the sticks. Then they drew a long straight line so: 1-_with Woma sticks at the ends, but as before a great wind came and swept away their work. The same thing happened again when they drew intersecting lines like this: poxm But all their trouble was in vain, for Watylina sent a wind each time to destroy their work.

$\Lambda t$ last they made a line so broad and so long that it made a great ridge, at each end of which they planted several Woma poles. While they were doing this the Mura-mura Mantandara came by and asked what they wore all doing there. Instead of telling him they laughed at his ignorance, so that he turned away ashamed and went away with a grudge against them. To have his revenge he turned himself into a fire and burnt up the other Mura-muras with their camp. After he had burned the Woma Mura-muras he also burned the Kapiri Mura-muras, KumariPuntali and Taraburuna, who had also made lines and set up sticks with Kapiri colours at the ends.

Out of the ashes of the Woma and Kapiri Mura-muras came Womas and Kapiris, and after these had returned to the ground countless young Womas and Kapiris came to light.

Notes my this kev. O. Sienert.

Naiyeni-mirara means "sluggard," from naijeni, slow, and mirara, comracle or mate.

Kurkali, derived from kurka, a kind of kangaroo-rat (Dieri and Wonkanguru).

Bulu-bulu, the designation of young Womas (I)ieri and Wonkanguru).

Watylina, to cook. 
Mantandara, a bush, in Dieri Wirra, the leaves of which are dried in the ashes, and being rubbed up are mixed with the pitcheri for chewing.

Kumari-puntali means "blood-drinker," from kumari, blood, and puntalato, drink (Wonkanguru. In Dieri Dapana).

Taraburuna means "he with the leg," i.e. having something the matter with his tara, or thigh.1

Certain bands of alternating red and yellow earth which show on the surface in serpentine curves not far south of the Queensland boundary are said to be the markings which the Mura-muras made.

Notwithstanding the burning of these Mura-muras they are spoken of as rocks "near the great lake," which may be Lake Eyre.

\section{V.-Kadiwonkuru. A LEgend of THE YaURorka.}

The wife of an almost blind Mura-mura named Makatakaba, who lived at Wityigurawimpa, went with her two daughters to collect nardoo for food. The two girls played about while their mother worked busily; and when she had gathered a quantity she dug a hole in the ground, poured the seeds in, and stirring them up let the wind blow the husks away. To prevent the good seed from being blown away she built up a breakwind of boughs. Next morning the three went out again for seed. The mother was busy as before collecting it, and the children played about, when they suddenly saw a great fire, of which they told their father when they returned to camp. When he heard of it he stood up, and lifting a child to each of his shoulders, asked them to point out the direction in which they had seen the fire. He said to the elder, "Can you see the fire?" and she answered, "Yes, father, I can see it quite plainly."

Then the old Mura-mura opened his eyes, and he who had been quite blind until then could see the smoke of the fire lying on the horizon like a great rain-cloud. His wife made him some paua from the nardoo, which he ate, and then lay down to sleep.

In the early morning he took a fire-stick, threw his bag over his shoulder, got ready to start, and said to his children, "I have a long journey before me, but you must not trouble about that;"

' [See supra., p. 88. - En.] 
and to his wife he said, "Take care of the children, so that no one may do them any harm." Then he stood up with his bag over his shoulder, a fire-stick on one arm and a small boomerang in his hand. With his first step he began to sing his zoapaia and to travel singing into distant parts.

His wapaia song commenced thus: "Dama-inda ngurpa, dama-inda ngurpalina," which means "leaving those belonging to me, I am going forth into the far-away;" and as he travelled along he put all that he saw-birds, snakes, kangarno tracks, trees, bushes, and whatever else he came across-into his song.

After travelling for a month he came to a great sandhill, from the top of which he saw a vast water. He went down the hill and waded into the water, seeing his own image reflected in it. He came back to land by a narrow passage which was being covered by the waters driven by a fierce wind. Then he climbed the highest hill near, and saw from it a great fire surrounding him. He sought to find out who had lighted the fire, but could see no traces of men, and thought it must have sprung up of itself. Even now, men say, this fire is always in that part, which is called the Wiluma country, and the people in it are the Yeroaviraye, or "fire-people."

Having gathered some hot coals from the fire, the Mura-mura went on his wanderings to the south, making his song, which is sung by the Urabunna.

While he was travelling thus, his wife and daughters were out one day gathering nardoo, and the mother was mending the katu or breakwind, to make it stronger before winnowing the seed, when one of her children came to her, and said, "Sce, mother, the great whiriwind coming up. Quick! make the katu strong, so that the wind cannot blow it away." So the mother used all her strength to make the katu fast, and when the whirlwind struck it they all three cowered behind it for shelter. But the wind blew stronger and stronger till at last it carried off the youngest girl. Then the other child was carried off, and finally the mother was lifted up by the furious blast.

Each night as the whirlwind swept along, carrying the woman and her two children, it rested, and wherever it did so a water hole was formed, not in a channel or hollow, but on the open dry tableland. Each morning it carried them further and further till it buried them at last in the distant northern sands. 
The Mura-mura Makatakaba travelled all the time towards the south carrying the hot coals which he had got in the Wiluma country and in time reached the Macumba country, where he came to a camp of people who were rubbing up and eating paua from the seeds of one of the gum trees. He was hungry, and asked for some of the food; but they took no notice and laughed at him because he was nenrly bald, with a long lock of hair hanging down behind, and had a small pointed beard. They also ordered him roughly away, and took no notice of his threats, when he said, "Do you think I have no wolkadra in my armpits?"

But they only shouted at him, "Yidni kutchi, yidni worana." Which means, "Are you a Kutchi? are you a Worann?" And they took up spears to throw at him.

The Mura-mura went sadly away with his finger on his lip, thinking of revenge. He did not go far away, but took a couple of coals out of his bag and set fire to the grass, saying to the flames, "Spread with great quickness." He put out the fire with his hands and went near to the camp again. There he took out more coals and again set the grass on fire, and in a moment he was standing in the midst of the flames. The people in the canp Iried to escape, but the quickly-spreading fire burnt then all up.

The old Mura-mura went on from camp to camp, but the loople were all unfriendly to him and made fun of his bald head, so he avenged himself by burning them up.

Notes ay thi Rev, O. SHebert.

Kadizonkuru comes from kadizwaru, lizard.

Mtakatakaba means "fje" in Wonkanguru. The Vaurorka name for this old Mura-mura was Kadiwonkuru, and the Dieri called him Kadiwaru (lizard) or "the Kadiwaru." The name Makatakaba was given to him later when he burned up the Wonkanguru and Ngarabana in their camps. It is only the latter part of the legend that is known to these two tribes, and is sung at their ceremonies. track.

Wityguru-zoimpa from wityguru, a whirlwind, and wimpa, a

Paua is food made from the seed of various plants. It is collected, cleaned, and stored away in pits, which are closed by a cover made of rushes and smeared on each side with clay to hold them together. The paua when taken out of the pits is placed in 
bags (wonduru) and either carried by the people or hung up in trees.

Nardoo is not ground, but pounded to a fine powder, and made into a kind of cake. When fish is plentiful, it is also stored up in the following manner. 'lhe fishes are first baked in the hot ashes, then the bones and insides being removed, they are laid on bushes on the ground to dry. When dry the skin is also removed, and the flesh is further dried till it is quite hard and can be pounded to powder and packed away in bags.

Wapaia is a song of travel which is sung at some of the sacred ceremonies by the tribes north of the Dieri and north of the Queensland boundary. 'The exact meaning of the opening phrase "Dama-inda-ngurpa" cannot be obtained, for the several informants are not even agreed as to the proper sound of the words, and give them different meanings. For instance the Yaurorka and Marunga sing the words, "Lamaa Lamanda ngurpa," \&c., without knowing their meaning at all, as is often the case with far-travelled songs.

Yiani kutchi, yidni zorana. Yidni is the vocative "thou," and kutchi a "debble-debble" that is believed to travel about in whirlwinds on mischief bent. Worana is a fabled creature, half man, half beast, living on an jsland in Lake Eyre.

Wolkadra is the same as the sacred churinga of the Arunta, and is carried concealed from all uninitiated persons in the armpit.

The "great water" reached by Makatakaba was probably the Gulf of Carpentaria.

\section{VI.-PIRINTI and Kapiri. A l.tegend of the URabunna ThInE.}

Iong ago Pirinti and Kapiri lived in great friendship at the north-west of Katitandra (Lake Eyre). At that time both had skins of the same colour, so they decided to paint each other.

First Pirinti had to paint Kapiri, which he did with a beautiful pattern. But when Kapiri had to paint lirinti he thought to himself, "Why should I give myself the trouble to make such intricate markings, when Pirinti is so much bigger than I am. I will make larger patterns on him." He therefore painted Pirinti with some large and some small patterns, and when I'irinti turned his head and saw the unequal pattern that Kapiri had put on, he said to himself, "I painted him very nicely, why has he done me so unequally ?" 
Kapiri said to him, "Do not turn round like that, you will rut off the paint." And as he said this he secretly rubbed off part of the pattern and ran away. Pirinti ran after him in great anger, but Kapiri was too nimble to be caught, so l'irinti shouted out to him not to dare to come into his ravine again, but to stay where the kulva grows, and Kapiri replied that in that case Pirinti must keep to the rocks and holes in the hills. Since that time there have been no Kapiri north of Oodnadatta, while at the Cooper, where the kulva grows, there are no Pirinti.

\section{Notes By M. E. B. Howitr.}

Kapiri and Pirinti are varieties of lizards.

Kulva is a hakea.

\section{VII.-Markanyankula. A Llegend of the WonkangukU and URABUnNa.}

The Mura-mura Markanyankula lived in Antyritya with his wife and many children. He used to gather nardoo and clean it by shaking it in his bowl, so that the refuse separated, then he packed it in kangaroo and 'possum-skin bags, put these in a larger bag, and started off on his wanderings, carrying the burden on his head.

The first place he came to was Arufolkandu on the Macumba River, where there was a level piece of ground. He loosened this ground and scattered the nardoo seed on it, so that when rain came it might grow and the people have plenty of food and not suffer any hunger. He also scattered nardoo in another place, and travelling on, came to Utyia, where he saw two docrepit old women, and said to them, "Look round about when the rain falls." When rain fell they went out as the Mura-mura Markanyankula had told them and looked about. They found the two places where he had scattered seed, where it had made the whole country green; the fruit was not ripe, but the women ate it and became healthy and strong. When the seed was ripe they gathered it into heaps and had plenty of food when the dry barren time came again.

After telling the old women what to do, the Mura-mura went to Pandi, whete a great number of men were collected to sing 
the Palpara song. He saw them a long way off, but was afraid to go near ; so he rested a while, and went on to Kadlikua, where two old men sat at the edge of the water throwing in their nets. But still he travelled further, scattering good and bad nardoo seed as he went, and calling the places where he left the latter Nardoomolku (bone nardoo).

At Kuyuna he stuck his spear into the ground, and it grew into a huge tree, and after he had wandered to Narimaia lake and the Pitchei country, he turned back and went to his own place and his own people.

Notes by the Rev. O. Siebert.

Arufolkandu means "making white or grey" from the quantity of dust there.

Macumba from "maka" fire, because the Mura-mura Makatakaba there burned a large camp.

Ityia $=$ a spring.

Pandi is to the north-west of Katitandra where the Macumba enters Lake Eyre. Pandi refers to a beast of legendary times, which was much feared.

Kadla kupa, a little creek or river, from the Wonkanguru $k a d l a=$ creek or river bed, and kupa $=$ child.

Kuyuna, the Diamantina River.

Narimaia is not a lake, but a wide creek bordered with trees, north of the Cattle Lagoon, and west-south-west from Birdville.

[Pitcheri is the Duboisia Hoprooodi, the leaves and twigs of which are dried and chewed. It is procured to the north of Lake Eyre.-M. E. B. Howitr.]

\section{Ngatant-Maru-Maru and Ngatani-Maralye. A LEGEND OF THE JIERI TrIBE.}

At Ngatani-maru-maru once lived a woman who had several dark-skinned children, and at Ngatani-maralye lived a woman whose children were lighter in colour.

The Ngatani-maralye mother longed for the dark-skinned children of the Ngatani-maru-maru mother; and one day when the latter had gone out to gather nardoo, leaving her children in the camp that they might not hinder her in her work, the Ngatani-maralye came with her light-coloured children and took away the dark-coloured children, leaving her own behind. 
The other mother, not knowing what had happened at the camp, came back about midday, carrying her nardoo in a halffilled bag on her hip. And on her way she met a nila-nila (mirage), and as it lifted her up from the ground she sang:

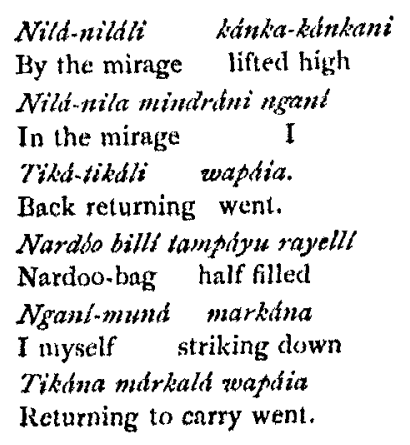

Coming nearer to her camp she looked longingly for her children in the place where they should be, and sang:

Milki milki nakalu.
The eye the eye only there.

Then she saw children playing about the camp, but not hers; they were strange ones with light skins; and putting down her bag among them she sang:

Wora wora zeolpana wora wora parabana.

To-the-right-and-left tumbling-over, to-the-right-and-Jeft lying-down.

Longing for her children she hastened round the camp searching in widening circles impatiently for their footprints, and driving herself onwards with her song:

$$
\begin{aligned}
& \text { Tidna kalya-kalyara ngatanina worana } \\
& \text { Foot quick to the children } \\
& \text { ngato wodakari Hgankana kurana worai } \\
& \text { I where doing left off. }
\end{aligned}
$$

Finding at last that her children had been carried off by the Ngatani-maralye mother, she sang complainingly: 
Lamenting thus, she crossed over a great plain to the home of the Ngatani maralye, who seeing her a great way off ran to meet her and gave up the dark-skinned children to her, taking back her own.

The Ngantani-maru-maru mother went back to her camp with her little ones; and next day left them as before in the camp while she went out to gather nardoo. But at middny she came back to find again the light-coloured children of the Ngatani-maralye mother in place of her own. Finding their tracks she followed them lamenting and brought them home. This happened every day till she set out on her wanderings. She sang as she went, but from lamenting much her voice had become so weak that she had to strain her throat to sing at all.

She wandered for some distance, when leaving her children she went on alone to Pando (Lake Hope), which was dry and white, and as she crossed it she sang:

\section{Tidna finta-pintarala kan ngani daka-dakala wapaia Foos on the salty expanse yes I to hard earth go.}

Further and further she wandered, till coming to Bau-ungbau-ung and Tyindi-tyindinani, when she sang:

Tyindi-tyindinani kan ngani daka-dakala wapaia.

To Tyindi-tyindiani yes I to hard earth go

Then she looked for hard clay soil, and when she had found it she sank underground singing :

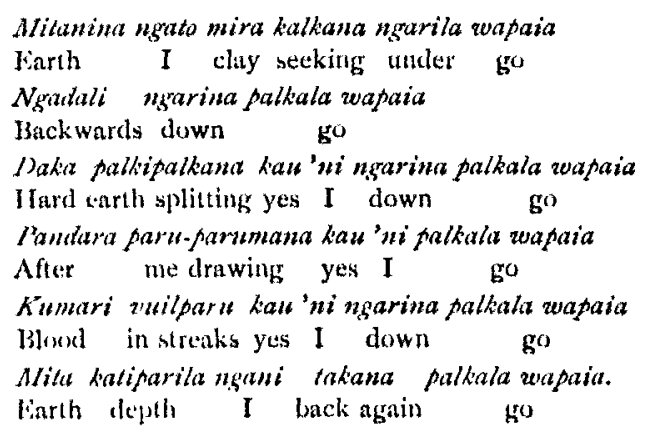

Finding a gaping cleft in the ground, she let herself slip into it and came to soil filled witl $d a k a$, which she broke up; hurting 
herself so that her tracks were marked with streaks of blood. Deep underground she pursued her way, only twice raising her head above the ground, until she reached her camp at Ngatani maru-maru. But here she only got nut of the ground as far as the top of her head, for her hair is still to be seen as dickeri (canegrass) standing in a great depression at Ngatani maru-maru.

\section{Notrs yy the Rrv. O. Simbert.}

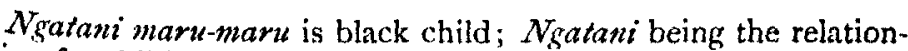
ship of a child to its mother, while Ngatamura is the relationship to the father. Maru is black or of a dark shade.

Ngatani-maralye is light-coloured child; Maralye being lightcoloured or reddish.

Kankana is to go up in the air, to mount up, also to strut.

$N_{g a n i}$ is the intransitive "I," while $N_{g}$ ato is the transitive pronoun, thus Ngani Dieri kupa is "I am a Dieri boy," while ngato nandrana is "I will strike."

Tikala zeapaia is the present tense of tikai, to return, or rather "to go to return"; wapaia is the imperfect of ngani wapai, I go.

Wora zeora wolpana, \&c. = to right and left, tumbling over unexpectedly.

Wora-wora paribana $=$ to make to lie down, to the right and left. Wora is "side," and Wora zoora, "on both sides," "right and left."

Tyindi tyindina and the Bau-ung Bau-ung districts are both south-east from Innaminka on Cooper's Creek. The first is named from shining (tyindi-tyindina) stones, and the latter from the trembling of the ground (bau-ung bau-ung-ingana).

Palkana is rather "to wander," while zopana is our usual word " to go"; the form wapaia, the imperfect of zeapana, is used for "I went to wander." Daka dakala wapara properly means "I went to cut through," or more precisely "to pierce the land."

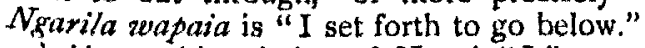

" $\mathrm{ni}$ is an abbreviation of $\mathrm{Ngani}$, "I."

Mitani is the dative of Mita, the ground, earth.

Karku or red ochre is thought by these aborigines to be the blood of the Mura-muras; hence they often say they have smeared themselves with blood when painted with red ochre.

The two places where the Ngatani Maru-maru mother raised her hands above ground are marked by large rocks.

M. E. B. Howrtr.

Vol. XIII, 